\title{
KEHOLLA, MIELELLÄ, RUUMIILLA
}

\section{Kehollisuuden asemia laulunopetuksen kulttuurissa}

Taiteiden myönteiset vaikutukset ihmisen psykofyysiseen hyvinvointiin ovat viime vuosina uineet keskusteluun taidealojen hyödyllisyydestä (Lehikoinen \& Vanhanen 2017: 7-9) erityisesti taidetta ja musiikkia harrastavien keskuudessa. Myös laulunopetuksen piiriin on rantautunut keskustelu siitä, millä tavoin laulaminen edistää ja ylläpitää ihmisen kokonaisvaltaista hyvinvointia. Hyvinvointikeskustelun lisäksi viimeaikainen musiikintutkimus sekä tutkimukset laulunopettamisen parissa ovat korostaneet teoreettisesti kehollisuuden merkitystä musisoinnissa ja laulunopetuksessa (esim. Juntunen 2009; Tiainen \& Kontturi 2007). Kokonaisvaltaisen kehollisuuden tutkimus esimerkiksi psykologian ja liikuntatieteen aloilla on myös tuonut uutta, kehollisuuden merkitystä korostavaa perspektiiviä keskusteluun kulttuurisista käytännöistä (esim. Jaakkola 2012; Leikola ym. 2016; Ogden \& Fisher 2015).

Tutkimuksen tarkoituksena on usein tarjota uutta tietoa, joka laajalle levittäytyessään vähitellen muuttaa toimintakulttuurin normeja. Vallitsevia käytännön normeja tarkastellen voidaan nähdä, millaista vaikutusta tieteellisellä tiedolla on varsinaiseen käytännön kulttuuriin. Kehollisuuden teoretisointi ja sen nostattama keskustelu muokkaavat siis kentän toimijoiden ajatuksia siitä, millaisia käytäntöjä kohti kentän tapojen olisi hyvä muuttua. Tässä artikkelissa kuitenkin 
keskityn ensisijaisesti siihen, millaisia käytäntöjä laulunopetuksen kentällä todellisuudessa juuri nyt on.

Laulunopetus ja lauluntutkimus olivat vielä viime vuosituhannen loppupuolella osittain törmäyskurssilla toistensa kanssa, sillä lauluntutkimus koettiin laulunopetusta haittaavaksi tekijäksi (Sonninen 1990: 70). Viimeaikaisen oppimisen tutkimuksen ja kokonaisvaltaisen kehollisuuden tutkimuksen tuottamat tutkimustulokset siitä, miten kehollisen maailmassa-olemisen tavat vaikuttavat ihmisen kokonaisvaltaiseen hyvinvointiin, herättävät tuota samaa keskustelua jälleen eloon: Pidetäänkö lauluinstrumenttiin liittyvää tutkimusta laulunopetuksen kentällä tärkeänä? Entä sovelletaanko tutkimuksen tuloksia varsinaiseen opetustoimintaan?

Laulunopetus on omanlaisensa kokoelma aikaansa sidottuja kulttuurisia käytäntöjä, jotka rakentavat itsensä yhteiskunnan arvojen, moraalikäsitysten, perinteiden ja niistä käydyn keskustelun ympärille (Herrala 2015: 33). Ne siis heijastelevat toimintakulttuuriin omaksuttuja arvoja. Tässä kulttuuritieteellisen näkökulman omaksuvassa artikkelissa tarkastelen tiettyjä käytäntöjä ja tapoja, joita on toteutettu suomalaisten julkisten ja yksityisten oppilaitosten tarjoamassa klassisen laulun ja pop/jazz-laulun opetuksessa. Pyrin artikkelissa vastaamaan kysymykseen, millaisia erityisesti kehollisuuteen liittyviä tapoja ja niitä ylläpitäviä arvoja vallitsevassa laulunopetuksen käytännön tason kulttuurissa painotetaan nykypäivän hyvinvointi- sekä kehollisuusdiskurssien viitekehyksissä. Tarkastelen myös, millaista huomioarvoa kehollisuudelle annetaan ja millaisia asemointeja keho saa laulunopetuksen kontekstissa.

Laulunopettajia sitovat taiteen perusopetusta antavissa oppilaitoksissa opetussuunnitelmat, joiden tarkka sisältö voi olla laitoksesta toiseen erilainen ja jopa opettajasta riippuvainen. Tunnustettujen oppilaitosten lisäksi laulunopetuksen alalla toimii kuitenkin myös paljon yksityisiä palveluntarjoajia, joiden tarjoama opetus ei ole opetussuunnitelmaan sidottua. Opetuksen käytännöt ovatkin hyvin kirjava ja runsas joukko erilaisia tapoja, sillä viime kädessä laulunopettajat päättävät itsenäisesti tavastaan opettaa. Opetuksessa saatetaan painottaa fysiologisiin faktoihin perustuvaa äänenhallintaa, kehotietoista, kehon kokonaisuutena huomioivaa holistista näkökulmaa, pyrkimystä esteettisyyteen tai ääniterapeuttista, hygieenistä näkökulmaa äänenkäyttöön laulamisessa. Opettamisen käytännön tavat voivat samoin vaihdella opettajien keskuudessa - joskus painotetaan 
enemmän tekniikkaa, toisinaan huomio kiinnittyy johonkin muuhun. Samoin laulua opiskelevien tavoitteet ovat monenlaisia - yksi tahtoo oppia tiettyä tyyliä, toinen monipuolistaa äänenkäyttöään ja kolmas esimerkiksi opetella pysymään vireessä laulaessaan. Tässä monenkirjavassa tavoitteiden, toiveiden, perinteiden ja päivittäisessä toiminnassa uusiutuvien käytäntöjen viidakossa vilisevät monenlaiset asenteet ja arvot.

\section{Laulaminen kehollisena toimintana}

Laulaminen on aina kehossa tapahtuvaa toimintaa (Lindeberg 2009: 239; Tarvainen 2012: 110), ja laulunopetusta voidaankin yksinkertaisesti kuvailla tapahtumaksi, jossa kehollista tietoa siirretään eteenpäin. Keho ja kehollisuus ymmärretään usein päivittäisessä puheessa pelkästään fyysisen ruumiin ulottuvuutena, mutta laulunopetuksen kentällä keholla tarkoitetaan fenomenologisen kehofilosofian mukaista mielen, ruumiin ja ympäristön yhteenliittymää (Merleau-Ponty 2012 [1945]: 52-53). Kehollisuus määrittyykin tässä artikkelissa fyysisen ruumiin, tajunnan ja tilanteisuuden yhteen kietoutuneeksi maailmassa olemisen tavaksi. Kehollisuus tarkoittaa siis fyysisen ruumiin sekä mielen muodostaman kokemuksellisen kehon tuntemista ja sen kanssa toimimista vuorovaikutuksessa oman ympäristön kanssa. Se on samaan aikaan sekä aktiivista että passiivista maailmassa olemista ja toimijuutta. Kehollisina olentoina suhtaudumme maailmaan sekä subjekteina että objekteina, vaikutamme ja tulemme samanaikaisesti vaikutetuiksi. (Merleau-Ponty 2012 [1945]: 482-483.) Fenomenologisessa kehofilosofiassa ajatellaan, että ihminen ei siis ole olemassa ilman ajatuksiaan, ruumistaan tai tilannetta, jossa olla olemassa. (Lindeberg 2005: 12-13; Turunen 2016: 36.)

Laulamisessa keho toimii yhtä aikaa sekä äänen lähteenä että äänentuoton välineenä. Sen voi myös ymmärtää eräänlaisena omalaatuisena instrumentiksi muotoutuvana organismina, joka rakentuu sitä mukaa, kun ihminen oppii sitä hyödyntämään (Tiainen 2012; ks. myös Shusterman 2008: 3). Tässä instrumentiksi tulemisen prosessissa kehoa voidaan pitää joko yksittäisistä, itsenäisesti toimivista laulun tuottamiseen osallistuvista osista koostuvana muotona tai yhtenä kokonaisuutena, jossa kaikki vaikuttaa kaikkeen. Tällaisen lauluinstrumentin määrittelyn vuoksi en tässä artikkelissa erikseen jäsentele klassiseen lauluun tai 
pop/jazz-lauluun liittyviä ominaispiirteitä, sillä itse instrumentti on suuntauksesta riippumatta sama, eikä eri laulunopetuksen koulukuntien välillä ole merkittäviä eroja suhtautumisessa kehollisuuteen. Sen sijaan tarkastelen yleisesti laulunopetuksen käytäntöjen heijastelemia, kehollisuuteen liittyviä arvoja.

Fenomenologisessa kehofilosofiassa ajatellaan olemisen lisäksi myös tietämisen olevan kehollista. Tämä kehollinen tietäminen tapahtuu oman kehon aistimusten, sen liikkeiden kuuntelun sekä sitä ympäröivän maailman vuorovaikutuksessa. Aistimisessa hyödynnetään sisäistä tasapaino-, liike- ja asentoaistia eli proprioseptistä tietoisuutta. (Uotinen 2010: 87.) Ihmisen oman kehollisen tiedon on myös havaittu auttavan hahmottamaan toisen ihmisen kehon liikettä ja kehollista viestintää. Oppimistilanteessa tällainen toisen kehoon samastumisen tunne myös motivoi oppimista. Kun koettua tilannetta vielä lisäksi reflektoidaan sanallisesti, syventää tämä sanallistaminen koetun ymmärrystä. Oppimistilanteessa kehollista kokemusta kuvaavat, samaistuttavat sanat voivatkin näin auttaa reflektoimaan ja ymmärtämään tätä omaa kokemusta uudella tavalla. (Juntunen 2009: 248-251.) Samoin voidaan ajatella, että kokemuksen syvällinen tarkastelu auttaa sanallistamaan sitä entistä paremmin.

Myös laulamisessa, sekä sen opettamisessa että oppimisessa, nivoutuvat yhteen fyysisen ruumiin, tajunnan ja ympäröivän todellisuuden tasot. Laulaminen on sekä fysiologista että kognitiivisen ajattelun muovaamaa toimintaa, johon liittyy olennaisesti myös sosiaalinen vuorovaikutus. Laulaminen on siis tulosta fysiologisen toiminnan ja henkisen sekä sosiaalisen motivaation yhteistyöstä. Sen vuoksi voidaan yksinkertaisesti todeta laulamisen olevan kehollista toimintaa. Uusmaterialistisen feminismin hengessä tässä artikkelissa pohditaan myös mielen ja ruumiin suhdetta painottaen niiden kehollisen tasapainon merkitystä laulunopetuksessa. Uusmaterialistinen, ruumiillinen näkökulma musiikin tekemiseen ja tekijyyteen korostaakin kehollisuuden kokonaisvaltaisuutta ja äänen ja ruumiin läheistä suhdetta toisiinsa. Tästä kulmasta katsoen ajatellaan ruumiin toimintojen muokkaavan äänen toimintaa ja vastavuoroisesti toisinpäin. (Tiainen \& Kontturi 2007: 25-48.)

Työssäni laulunopettajana olen huomannut, että oman kehollisuuden havainnointi on useimmille ihmisille jokseenkin vierasta. Tutumpaa on oman kehon tuntemusten havainnoinnin sijaan tarkkailla omaa mieltä ja ajatuksia, mikä näkyy laulunopiskelijoilla erityisesti epätietoisuutena omasta kehosta sekä vaikeuk- 
sina hahmottaa omaa kehoa. Oman kehon kuuntelu jää siis usein mielen ja ympäristön tarkkailun jalkoihin, eivätkä oman kehon muoto tai sen liikkeet hahmotu selvinä ruumiillisten tuntemuksien kautta (Shusterman 2008: 6). Ilmiö ei rajoitu vain laulamisen kontekstiin: esimerkiksi liikunnan ammattilaisilla oman kehon palautteen kuuntelu on huomattu heikoksi, vaikka oma keho ja sen viestimä palaute ovat heidän tärkeimpiä työkalujaan (Lyyra 2017: 14). Mielen ja fyysisen ruumiin kommunikointiin käyttämät keinot ovatkin toisistaan eroavaisia: äly turvautuu puhuttuun kieleen ja sanoihin, kun taas ruumis viestii nonverbaalisin koodein (Fiske 1990: 67).

\section{Autoetnografinen näkökulma}

Kulttuurintutkijan asemani lisäksi olen myös musiikkipedagogi (АМК) ja toimin laulunopettajana. Olen opiskellut laulua 17 eri opettajan johdolla musiikkiopistossa, kahden eri konservatorion musiikkiopistotasolla, ammattikorkeakoulussa sekä mestarikursseilla. Laulaminen lapsikuorossa sytytti kipinän yksinlaulun opiskeluun, jonka aloitin vuonna 2004 ollessani kolmetoistavuotias. Sen jälkeen opintieheni on kuulunut musiikkilukiossa laulun ja bändisoiton opiskelu, musiikkiopistossa klassisen laulun opiskelu aina D-tutkintoon asti, ammattikorkeakoulussa pop/jazz-laulun B-tutkinnon suorittaminen ja laulunopettajaksi opiskeleminen, laulunopettajana toimimista yksityisessä musiikkikoulussa, kansalaisopistoissa, musiikkiopistossa sekä palveluntarjoamista toiminimellä vuodesta 2015 lähtien.

Etnografit Aromaa ja Tiili (2014: 260) kirjoittavat, että herkkyys tarkastella ja aistia sekä ruumiillisesti että emotionaalisesti sitä, mitä kentällä tapahtuu yhdessä tutkijan sanattoman informaation tulkintataidon kanssa ovat erottamaton osa etnografista tutkimusta. Alan tutkimuksissa ajatellaankin, että etnografia sisältää aina jotain henkilökohtaista tulkintaa ja on siten myös jo valmiiksi osin autoetnografiaa (Granger 2011: 31). Sen vuoksi voidaankin ajatella, että kaikki kokemukseni laulunopiskelun kontekstissa on pitkäjaksoisen havainnoinnin myötä koostunutta (auto)etnografista aineistoa. Valitsemani aineistonmuodostuksen menetelmät polveilevatkin sujuvasti perinteisen etnografian ja autoetnografisen tutkimusotteen rajapinnoilla. 
Tämän artikkelin keskiössä olevat keholliset kokemukset ovat sellaista henkilökohtaiseen kuuluvaa aluetta, jonka ymmärtämiseksi tutkijan on tarkasteltava myös omia kokemuksiaan. Laulunopetus ja kehollisuus ovat kumpikin sisäisiä kokemuksia, joita on hankalaa tarkastella ainoastaan ulkopuolelta. Laulunopetuksen ja kehollisuuden ilmiöiden tarkastelu vaatii tutkijalta myös oman kokemuksen tarkastelua, sillä tutkijan omat kokemukset ilmiöstä ovat tärkeä osa aineiston tulkintaa ja edellytys tarkasteltavana olevan ilmiön syvälliselle ymmärtämiselle. Sen vuoksi hyödynnänkin omia kokemuksiani laulunopiskelijana ja laulunopettajana tämän tutkimuksen aineistona ja viitekehyksenä.

Tutkimuksen aineisto koostuu itsereflektion kautta tuotetuista henkilökohtaisista dokumenteista, puolituntisesta äänitteestä sekä kymmenen standardiliuskaa käsittävästä muistelupäiväkirjasta, jossa reflektoin minulle pidettyjä laulutunteja viimeisen 15 vuoden ajalta ja avaan omaa polkuani laulajana ja laulunopettajana. Muistelun keskiössä ovat laulutuntien konventiot ja erilaiset kohtaamani opetustyylit. Tätä hyödyntämääni autoetnografisen aineiston muodostamisen menetelmää kutsutaan itsensä haastattelemiseksi, dialogiksi menneen ja nykyisen itsen välillä (Anderson \& Glass-Coffin 2013: 68). Henkilökohtaisten kokemusteni tukena toimivat myös reflektiot kollegoiden kanssa käydyistä keskusteluista sekä kokemukseni laulutuntien seuraamisesta (Chang 2013: 108). Lisäksi olen koonnut kyselylomakkeen avulla vertaisaineistoa, joka sisältää kokemuksia laulunopiskelusta. Vastaukseksi saamani 16 lauluopintoja reflektoivaa kirjoitusta eri oppilaitostasoilla työskenteleviltä laulunopettajilta ja laulunopiskelijoilta sekä tukevat että ruokkivat koostamaani autoetnografista aineistoa.

Aineistoa analysoitaessa on huomionarvoista, että jokainen ihminen kokee asiat eri tavoin, ja varsinkin näin tiukasti henkilökohtaiseen kokemukseen liittyvässä aiheessa tavat sanoittaa kokemuksia voivat olla sangen eriäviä. Autoetnografinen tutkimusote kuitenkin palvelee nimenomaan tällaista tutkimusasetelmaa, sillä tutkijan omat kokemukset ja syvällinen ymmärrys tutkittavasta ilmiöstä auttavat hahmottamaan kentällä esiintyviä erilaisia termejä ja käsitteitä sekä sijoittamaan ne kontekstiinsa mahdollisimman hyvin. (Bochner 2013: 53.)

Autoetnografia menetelmänä käyttää tutkijan omia kokemuksia tutkittavana olevan kohteen kuvailuun ja kriittiseen tarkasteluun. Tähän menetelmään kuuluu myös vahvasti reflektion kautta tuotettu aineisto sekä tämän reflektion kautta tuotettu uusi tieto. (Jones 2016: 18-20.) Tässä artikkelissa tarkastelenkin refleksiivisesti aineistoni tarjoamia teemoja kehollisuudesta laulunopetuksessa. 


\section{Kehollisuus ja kuuntelu}

Laulunopettaja kuuntelee toista ihmistä niin sanotusti empaattisesti omalla kehollaan. Keholla kuuntelu tarkoittaa sellaista äänen kuuntelemista, jossa opettaja aktiivisesti havainnoi oppilaan ääntä tuntemuksina omassa kehossaan (Tarvainen 2012: 130). Näitä kuuntelun kohteita ovat muun muassa kielen, kurkunpään, pallean ja muun hengitys- ja tukilihaksiston toiminta. Opetuksen kentällä ei ole muodostunut yhtenäistä havainnointimenetelmää, sillä opettajat kuuntelevat oppilaita eri tavoin oman kuuntelutapansa sekä ajan mittaan kertyneiden lauluja opetuskokemustensa mukaisesti. Laulunopetuksen kehollisen luonteen vuoksi laulunopettajalta vaaditaan tietynlaista tietoisuutta omasta kehostaan. Ilman taitoa havainnoida omaa kehoaan opettaja ei kykene havainnoimaan myöskään toisen kehoa.

Tätä taitoa kutsutaan eri lähteissä muun muassa audiokinesteettiseksi kyvyksi tai luovaksi kuulemiseksi (Eerola 2008: 18). Sitä voidaan kutsua myös vitaaliaffektien aistimiseksi ja empaattiseksi kuunteluksi (Tarvainen 2012: 25, 205), jotka ovat rinnastettavissa proprioseptisen tietoisuuden havainnointiin (Klemola 2005: 85). Neuropsykologisesti saman voi selittää peilisolujen aktivoitumisena ja hyödyntämisenä, mikä tarkoittaa, että toisen ihmisen suorittamaa liikettä katsellessa katselijan oma hermosto aktivoituu samankaltaisesti, ikään kuin hän itse suorittaisi vastaavaa liikettä (Debes 2017: 54). Myös musiikkikasvatuksen tutkimuksessa on havaittu ihmisen oppivan katselemalla ja matkimalla toista ihmistä. Esimerkiksi mielikuvan avulla liikkeen kuvittelemisen on havaittu aktivoivan hermostoa todellisen liikkumisen tapaan. (Juntunen 2009: 248.) Tässä artikkelissa nämä edellä mainitut ilmaisut nivoutuvat keholliseksi kuunteluksi.

Kehollinen kuuntelu on siis taito, jota opettaja hyödyntää työssään. Kuuntelun taito on yksilöllinen ja toisinaan riippuvainen myös muusta opettajan ja oppilaan välisestä persoonallisuuksien ja temperamenttien yhteensopivuudesta. Laulunopetuksessa on ensiarvoisen tärkeää, että opettaja ja oppilas puhuvat niin sanotusti samaa kieltä tekemistään havainnoista. Väitettä tukee se, että tähän artikkeliin kerätyssä tutkimusaineistossa laulamisesta työuraa suunnitelleita opiskelijoita hämmensi heidän omissa lauluopinnoissaan kaikkein eniten puutteellinen kommunikointi: "Opettajien keskenään ristiriitaiset ohjeet, mututuntuma opetuksessa" (V4 k2019). "Termien käyttö: sama termi voi tarkoittaa kaikille eri 
asiaa" (V3 k2019). "[Tilanteet,] joissa opettaja ei osaa selittää asiaa niin, että se aukeaa myös minulle" (V6 k2019). "Käsitteiden abstraktius, mielikuvat, jotka ois pitäny älytä" (V14 k2019). "Se, kuinka laulunopetus on eräänlainen villi länsi, jossa vallitsee todella paljon erilaisia uskomuksia" (V16 k2019).

Laulunopettamisen abstraktius hankaloittaa monesti ymmärretyksi tulemista molemmin puolin, sillä puheenaiheena ovat sellaiset sisäiset asiat, joille ei ole olemassa yhtä selkeää nimitystä ja joita ei usein voi nähdä tai konkreettisesti käsin tunnustella. Kommunikaation epäonnistuessa jaettu yhteinen kokemus vallitsevasta tilanteesta jää puuttumaan, jolloin useimmiten oppilas hämmentyy: enkö ymmärräkään, mistä on kyse?

Ilmaisu "kuuntelu" sisältää ajatuksen toisen ihmisen arvokkuudesta. Kun minä kuuntelen sinua, osoitan sillä ilmaisusi olevan minulle merkityksellistä. Tavalla, jolla opettaja kuuntelee oppilastaan, on siis opetuksen onnistumisen kannalta suuri rooli. Jos oppilas kokee, että opettaja aidosti keskittyy hänen ilmaisuunsa ja tuntee olonsa kuulluksi, palaute tekemisestä piirtyy hänelle todennäköisesti positiivisesti. Jos taas oppilaan ja opettajan käsitykset tilanteesta ovat ristiriidassa, eikä oppilas koe, että häntä kuunnellaan aidosti, voi tilanteesta pahimmillaan aiheutua oppilaalle psyykkistä vahinkoa. (Sinkkonen 2009: 292.) Näin syntyneet vauriot voivat esimerkiksi vaikuttaa rajoittavasti oppilaan ilmaisulliseen itsetuntoon. Hyvinvoinnin näkökulmasta laulunopettamiseen liittyvän kehollisen vuorovaikutuksen ja kuuntelun toimivuus onkin erittäin tärkeää.

Jos opetustuntien sisällössä laulamisesta nauttiminen jää tavoiteoppimisen jalkoihin, on hyvä pitää mielessä nuorten musiikkiharrastuksen lopettamisen suurimmat syyt: harrastuksen suorituskeskeisyys, nuoreen kohdistuvat paineet, epäonnistumisen ja syyllisyyden tunteet soittamisesta, kun läksyjä ei jaksa tai ei ole motivaatiota harjoitella (Yle 2010). Musiikkiopistojen kurssit ovat pitkään tähdänneet tutkintojen suorittamiseen, ja opintojen on ollut tarkoitus antaa valmiudet musiikin ammattiopintoihin. Nykyisessä taiteen perusopetuksen opetussuunnitelmassa kuitenkin korostetaan erityisesti positiivista, elämän mittaiseen musiikin harrastamiseen kannustamista. Asenneilmapiiri muuttunee siis hiljalleen siihen suuntaan, että myös musiikkioppilaitoksessa saa harrastaa musiikkia ja laulamista vain nauttiakseen siitä. 


\section{Kulttuurisesti määrittynyt lauluääni}

Laulunopetuksessa eteenpäin siirrettävä kehollinen tieto voidaan lyhyesti tiivistää tapahtumaksi, jossa opetetaan eri taajuuksien ja äänenvärien tuottamisen hallintaa. Laulunopettajalla on aina itsellään jonkinlainen käsitys siitä, millaiselta hyvä lauluääni kuulostaa. Ilman tätä oletusta opettaminen vaikeutuisi huomattavasti, sillä se ohjaa opettajan kuuntelua ja sitä, mihin suuntaan hän opetustaan alkaa tietyn oppilaan kanssa viedä. Tämä oletus voi olla yksinkertaisesti puhdas, soiva ääni tai tietty esteettisen soinnin malli.

Kulttuurisesti määrittynyt oletus hyvästä lauluäänestä vaikuttaa siis mielikuviin siitä, millainen lauluäänen pitäisi olla. Pyrkimys tämän kulttuurisen oletuksen toteuttamiseen johtaa tilanteeseen, jossa toiset äänet saavat olla kuuluvilla ja toiset eivät. Siten ne määrittävät kulttuurissaan hyväksyttyjä ja kartettuja ääniä. Laulutunnilla opettajalla on käytettävissään suuri, usein jopa tiedostamaton valta, jolla on voima vaientaa tai voimaannuttaa oppilaan äänellistä ilmaisua, minkä myötä kulttuurinen lauluäänen määrittely elää laulunopetuksen arjen käytännöissä. Opettajalla onkin näin opetustilanteessa valta vaikuttaa oppilaan hyväksytyksi tai hylätyksi tulemisen kokemukseen (Huhtinen-Hildén 2012: 38).

Kulttuurinen malli ihanteellisesta äänestä on ytimekkäästi määritelty esimerkiksi tasaisesti soivaksi ja kiinteäksi ääneksi,

joka on vapaa kaikista sivuäänistä, vääristymisistä ja virheellisistä jännityksistä, joka tarpeen mukaan soi ylä-äänissä joko hiljaisena tai voimakkaana, joka virtaa kevyenä ja kauniisti resonoivana eikä aiheuta laulajalle minkäänlaista lihaksiston virhetoimintaa (Numminen 2005: 47).

Hyvää laulajaa voidaankin tämän pohjalta luonnehtia ilmaisussaan vapautuneeksi, äänensä koko potentiaalia hyödyntäväksi ja ääntään "terveellä" tavalla käyttäväksi laulajaksi. Hyvä lauluääni ei toisin sanoen ole liian pingottunut, vuotoinen, puristeinen, passiivinen tai kireä. Sen sijaan se on vapaa, soinnikas, sopivan kiinteä, aktiivinen ja rento.

Tämä kulttuurinen malli hyvästä lauluäänestä määrittää myös laulunopettajien toimintaa opetuksessa - millaisen äänen ajatellaan olevan hyvä ja arvokas sanelee sen, mihin suuntaan oppilaan ääntä muokataan. Kulttuurinen lauluää- 
ni tarkoittaa siis eräänlaista laajareunaista ihannetta, jota kohti ääntä pyritään laulunopetuksessa erilaisten tyylienmukaisten rajoitusten mukaisesti muokkaamaan. Samaan aikaan se myös määrää, millaisia arvoja opetuksessa noudatetaan.

\section{Kehollisuus - ääni - esteettisyys}

Laulaminen tuntui olevan täynnä sääntöjä, mutta vapaa ilmaisu loisti poissaolollaan. (V2 k2019)

Vaikka laulamisen opettelun päämääränä on tavoitella ihanteellisen lauluäänen rentoa, soivaa virtaavuutta, muotoutuu laulutunti itsessään usein teknisen, fyysiseen harjoitteluun liittyvän suorittamisen ympärille. Tätä perustellaan usein sillä, että laulun tekninen puoli tulee hallita, ennen kuin heittäytymisen tulkinnallista ja ilmaisullista eli henkistä puolta voidaan soveltaa laulamiseen. Keskustelussa laulunopetuksesta vallitseekin yleinen mielipide siitä, että jokaisen laulajan täytyy tietää, miten instrumenttiaan käyttää, ja että laulutekniikan opiskelu mahdollistaa entistä monipuolisemman äänen käytön (ks. esim. Hautamäki 2002: 7; Koistinen 2003: 27). Vaikka laulunopetuksen haaste piilee kehollisessa kuuntelussa, laulamisen fyysisen puolen tarkkailu korostuu kuitenkin opetuksessa enemmän kuin henkisen puolen tarkkailu. Opetuksessa keskitytään usein enemmän näistä toiseen, jolloin toinen puoli jää vähemmälle huomiolle ja kokonaisvaltainen kehollinen oleminen häiriintyy.

Laulunopetuksen kentällä polarisoituu erityisesti kaksi erilaista opettamisen tapaa, jotka määrittelen tässä artikkelissa äänellis-esteettiseksi ja kehollis-äänelliseksi tyyliksi. Nämä tyylit erottuvat sekä kyselyaineistostani että autoetnografisesta aineistosta kahtena yleisimpänä suuntauksena opettaa laulua.

\footnotetext{
Aloimme tunnin yleensä teknisellä harjoitteella, jota pohjustettiin opettajan omalla ääni-esimerkillä. Tarkoitukseni oli ensisijaisesti matkia opettajan antamaa esimerkkiä. Jos tein asian oikein, en useinkaan ymmärtänyt, mitä tein oikein, eikä opettaja sitä minulle selittänyt. Vääränlaisia ääniä korjattiin esimerkiksi ohjeilla "älä killitä", "avaa putki" ja "soita resonanssia". Oikeanlainen ääni oli pääasia - varsinaisella fysiologisella tapahtumalla ei niin väliä. (Havukainen mpk2018: 4.)
} 
Edellinen äänellis-esteettistä tyyliä kuvaava lainaus on ote muistelupäiväkirjastani. Äänellis-esteettisesti painottuneessa laulunopetuksessa korostuu erityisesti äänen esteettisen soinnin tavoittelu. Tämä tyyli on sukua esteettiselle musiikkikasvatukselle, jonka mukaan musiikin esteettisyys määrättynä tavoitteena itsessään on prioriteetti varsinaisen musiikin tekemisen sijasta. (Numminen 2005: 42.) Esteettinen äänenkäyttö painottuu luonnollisesti erityisesti klassisen laulun ja jazzlaulun opetuksessa, sillä ne ovat eksakteja laulutyylejä, jotka määrittyvät ajasta toiseen esteettisten perinteidensä kautta. Lauluja harjoitellaan näitä tyylejä edustavien opettajien opissa laulamaan ensisijaisesti musiikin vaatimaa estetiikkaa käyttäen. Esimerkiksi äänensävyn täytyy olla tarpeeksi tumma tai kirkas, teksti täytyy tuottaa oikeaa lausuntatapaa käyttäen ja sointi sekä rytminen fraseeraus täytyy pitää riittävän oikeaoppisena.

Suomalainen musiikkikasvatus on kouluissa ja musiikkiopistoissa pohjautunut pitkään esteettiselle musiikkikäsitykselle. Esteettisessä systeemissä niin laulajan ilmaisu kuin myös keho arvotetaan sen kantaman esteettisen arvon mukaisesti, ja tähän esteettiseen perinteeseen sopimattomat äänet on suodatettu esimerkiksi pääsykokein pois musiikin perusopetuksen piiristä. (Numminen 2005: 44-47.) Äänellis-esteettisesti painottunut opetus on jatkumoa tälle perinteelle, jossa keskitytään ensisijaisesti siihen, miten oppilaan kehon ominaisuuksia muokataan mekanistisella ajattelulla tietyn esteettisen soundin aikaansaamiseksi. Tällaisessa tilanteessa keho asemoituu välikappaleeksi, jonka tarkoituksena on konkretisoida itsessään arvokas esteettinen musiikkituotos. Voidaan väittää, että äänipainotteinen opetuksen tapa ylläpitää kulttuurista mallia hyvästä lauluäänestä sekä samalla mystifioi laulajaksi syntymistä.

[Opettajani] havainnoi taitavasti vireystilaani laulutuntien aikana, ja pyrki antamaan minulle täsmällisesti siinä hetkessä mahdollisesti toimivia neuvoja rentouttaa tai aktivoida kehoani. Ollessani passiivinen hän muutti omaa olemustaan aktiivisemmaksi, ja kun hän pyysi minua vaikkapa avaamaan enemmän rintakehääni, hän näytti sen minulle omalla kehollaan esimerkiksi. Samoin [opettaja] kuunteli äänentuottoani niin tarkasti, että hän pystyi paikantamaan kehossani toiminnan, joka aiheutti kireyttä ääneen. (Havukainen mpk2018: 5.) 
Edellä kuvailemani opetustyyli edustaa puolestaan kehollis-äänellisesti painottunutta opettamista. Kehollis-äänellisesti painottuneen opetustavan omaksunut opettaja kuuntelee oppilasta aktiivisesti omalla kehollaan ja pyrkii olemaan kehollisesti läsnä vuorovaikutuksessa oppilaan kanssa. Opetuksen tavoitteena on huomioida erityisesti kehon toimintaa ja muuttaa lauluteknisiä toimintoja kehoa kuunnellen - tällöin keho itsessään asemoituu tärkeäksi toimijaksi, jonka ehdoilla ääntä tuotetaan. Kehollis-äänellinen opetustyyli laskeutuu lähemmäs praksialistista musikaalisuuskäsitystä (Elliott 2014), jonka mukaan jokainen ihminen on potentiaalinen oppimaan musiikillisia taitoja.

Kehollis-äänellisesti painottuneessa opetuksen tavassa keho asemoituu pelkkää ääntä merkityksellisemmäksi objektiksi. Ei voida kuitenkaan sanoa, ettei lopputulokseksi muotoutuvalla äänellä olisi merkitystä, sillä aina kun laulua tuotetaan, sitä tuotetaan jonkinlainen esteettisyyskäsitys mielessä. Kehollis-äänellisesti painottuneen opetustavan moraali kuitenkin asettaa kehon ehdoilla toimimisen tiukkaa äänen estetiikkaa tavoittelevan toiminnan yläpuolelle, mikä heijastelee praksialistista käsitystä musiikin oppimisesta: tärkeämpää on itse tekeminen, ei lopputulos. Näkökulma kietoutuu myös uusmaterialistiseen näkemykseen siitä, että musiikin tekeminen itsessään on tärkeämpi havainnoinnin kohde kuin jo soinut, historiaan jäänyt soiva musisoinnin lopputulos (Tiainen \& Kontturi 2007: 25).

\section{Kehollisuuteen nivoutuva toiminta}

Äänellis-esteettinen ja kehollis-äänellinen lähestymistapa jakautuvat molemmat sekä mielikuvapohjaiseen että teoreettisiin faktoihin pohjautuviin opetuksen tapoihin. Mielikuviin nojaava opettaja saattaa esimerkiksi pyytää oppilasta ajattelemaan haukkaavansa suurta omenaa, jotta oppilaan leuka aukeaisi oikein. Teoreettisiin faktoihin opetuksensa perustava opettaja voi puolestaan samanlaisessa tilanteessa pyytää oppilasta laskemaan leukaansa nivelestä suoraan alaspäin. Tavoite molemmilla opettajilla on sama, saada leuka aukeamaan oikealla tavalla, mutta tavat sanoittaa pyyntö ovat erilaisia. Yksi ja sama opettaja voi myös vaihdella ohjeiden pukemista sanoiksi oppilaan oman hahmottamistavan mukaisesti. 
Heti ensimmäinen opettajani sanoi, että jos jokin laulaessa sattuu tai tuntuu pahalta, niin lopeta. (V2 k2019)

Riippumatta opetustyylin painottuneisuudesta yleisesti jaettu käsitys on, että laulamisen tulee tuntua fyysisesti hyvältä. Muistan myös itse useiden eri tyylejä edustavien opettajien sanoneen minulle, että mikäli laulaminen sattuu tai tuntuu pahalta, jotain menee tekemisessä pieleen. Näitä ongelmia opettajat puolestaan käsittelevät eri tavoin omasta painotuksestaan käsin. Fyysisiä ongelmia ratkottaessa asiaa lähestytään usein kehopainotteisemmasta näkökulmasta. Opetuksen kannalta ratkaisevaa on, kuinka kauan tätä painotusta ylläpidetään.

\begin{abstract}
Alkaessani käydä laulutunneilla koin useasti kiristävää tunnetta kaulani alueella, enkä itse vielä osannut paikantaa, mistä on kyse. Yksi opettajistani koitti saada ongelmaa ratkeamaan keskittymällä hengitykseni aktivoimiseen, jolloin paine kaulan alueelta hälvenisi. Toinen opettaja kuunteli ainoastaan ääneni sointia ja kehui sitä oikeanlaiseksi, vaikka minuun edelleen sattui. Koin, ettei reflektiollani ollut opettajalle merkitystä, ja opin olemaan asiasta hiljaa. Vasta myöhemmin eräs seuraavista opettajistani selitti minulle, että kireys kaulani alueella johtuu jännitteisestä kurkunpäästä ja opetti, miten tätä aluetta voi rentouttaa. Silloin koin myös ensimmäistä kertaa, etten olekaan laulajana toivoton tapaus, vaikken ollutkaan niin sanotusti luonnollisesti syntynyt laulajaksi. (Havukainen mpk2018: 6.)
\end{abstract}

Koska kehon erilaisille jännitystiloille on monenlaisia syitä, on oppilaan oikeanlaisten liikeratojen oppimisen vuoksi tärkeää kiinnittää huomiota siihen, mikä kehossa jännityksen varsinaisesti aiheuttaa. Työssäni olen havainnut esimerkiksi leuan, huulten, kielen, pallean ja rintakehän olevan eniten jännittyneitä kehon alueita. Leuka, huulet ja rintakehä ovat näistä paikoista konkreettisesti näkyvimpiä, silmin havaittavia asioita, joihin opettajan on vaivatonta puuttua. Näiden yksittäisten kehon osien tarkkailuun suunnattu huomio verottaa kuitenkin toisinaan kokonaisvaltaisen kehon huomiointia, ja kehollinen kuuntelu voi opettajalta tällöin unohtua. Tällaisessa tilanteessa kokonaisvaltainen kokeva keho jää jälleen lopputuloksessa varjoon. 
Laulaessa keho liikkuu sekä sisäisesti että myös ulkoa päin tarkasteltuna niin hengityksen, ilmaisun kuin musiikinkin tahtiin. Sisäinen liike tarkoittaa, että havaitsen esimerkiksi hengitys-, tuki- ja ääntöväylän toimintaan liittyvien lihasteni liikkeitä proprioseptisesti. Lauluopinnoissani olen havainnut, että laulugenrestä riippumatta sisäinen liike ja sen hallinta on laulamisen kannalta olennaisen tärkeää. Sen sijaan ulkoiset liikkeet, kuten musiikin rytmiin liikkuminen laulaessa, jakavat mielipiteitä eri musiikkiperinteiden kesken.

Kehollisen tiedon ja eri taajuuksien ja äänenvärien harjoittelun lisäksi laulamisen opiskelu voidaankin määritellä myös kehon sisäosien liikkeiden hallinnan opetteluksi. Tällöin keho asemoituu oppimisen prosessissa rakentuvaksi instrumentiksi. Aineistossani sisäisen liikkeen koetaankin markkeeraavan laulajan aktiivisuutta ja sen katsotaan auttavan ylläpitämään laulajan käsitystä esimerkiksi musiikin temposta, intensiteetin vaihteluista sekä tuotetuista sävelkorkeuksista ja äänen laadusta. Ulkoisen liikkeen koetaan puolestaan useimmiten kompensoivan tätä sisäistä liikettä - ikään kuin ulkoisen liikkeen suorittaminen helpottaisi saman tuntuisen sisäisen liikkeen tekemistä. Oppilasta saatetaan esimerkiksi kehua elastisesta kehon käytöstä, kun taas toisinaan niin sanottua ylimääräistä liikettä pyritään karsimaan.

Harjoittelin kappaletta pianistin säestyksellä ja hytkyin kevyesti kappaleen pulssia joustamalla polviani. Opettajani sanoi minulle vihaisena, että "ole liikkumatta!" ja uhkasi tulla pitämään polvistani kiinni, jos vielä ilmentäisin pulssia jaloillani. (Havukainen mpk2018: 4.)

Klassisessa laulussa rytmisen liikkumisen ei usein nähdä olevan tyylinmukaista eikä suotavaa, sillä musiikin pulssin korostaminen ei kuulu klassisen laulun estetiikkaan. Sen vuoksi sitä pyritään karsimaan myös opetettaessa. Sen sijaan esimerkiksi ääni ja sen karisma koetaan klassisessa laulutyylissä itsessään tärkeiksi, ja temposta riippumaton liikkuminen sekä näyttelijäntyöhön liittyvien seikkojen korostaminen liikekielessä kuuluu klassisen laulutyylin perinteisiin. Äänen asema nousee väistämättä tällaisessa katsannossa kokonaista kokevaa kehoa merkittävämmäksi, mikä voi puolestaan olla syynä kokonaisvaltaisesti kokevan kehon vähempiosaiselle huomioinnille äänen esteettiseen karismaan nojaavissa opetustyyleissä. 
Ulkoisen liikkeen hyödyntämisestä sisäisen liikkeen oppimisessa voi kuitenkin esimerkiksi visuaaliselle tai kinesteettiselle oppijalle toisinaan olla myös apua. Esimerkiksi melodisesti haastavan kohdan visualisointi käden liikkeellä auttaa hahmottamaan sävelmän kulkua ja siirtämään tämän havainnon omaan lauluun. Myös jonkin rytmisesti haasteellisen kohdan opettelussa oman kehon tuottama rytmiikka, kuten marssiminen tai taputtaminen, voi olla hyödyksi ja auttaa lauluoppilasta hahmottamaan poljennon ja laulun tekstin asettumista kohdalleen. Havaitsen itse laulaessani musiikin melodian, rytmin ja sointivärin kehossa erilaisina suuntina, nykäyksinä ja laajentumisina. Myös opetuksen termistössä käytetään näihin mielikuviin nojaavia käsitteitä, kuten "äänen etinen sointi", "keskivartaloa laajentava hengitys" tai "musiikin pulssin tuntu".

Kehon kokonaisuutta huomioidaan siis laulutunnilla harvemmin kuin yksittäisiä kehon osia. Vaikka laulunopettajan kehokäsitys pohjautuisikin oletuksellisesti koko kehon instrumenttiuteen, koko kehon huomiointi jää kuitenkin käytännössä laulutunnilla yksittäisten kehon osien huomioinnin varjoon. Tällainen näkökulma asemoi kehon mekaaniseksi äänenkäytön välineeksi, jonka eri osia "ruuvaamalla ja vääntämällä" löydetään niin sanotusti sopivat asetukset, joissa ääni soi miellyttävästi. Keho on kuitenkin kokonaisuus, jossa yhden osan liikuttaminen vaikuttaa kaikkiin muihin osiin (Richter 2010: 1). Esimerkiksi koko leuan alueen rentouttamiseen kuuluu leukalihasten rentouttamisen lisäksi myös kielen, kaulan lihasten ja kurkunpään rentouttaminen. Tällaisessa mekanistisessa ajattelussa unohtuu usein myös ihmisyyden muut ulottuvuudet: tunteet, kokemukset ja sosiaalisuus.

\footnotetext{
Omalla kohdallani jatkuva tietyn leuan kohdan rentouttamiseen keskittyminen sai kielenkantani jännittymään, ja kun opettaja kuuli edelleen äänessä kireyden leuan alueella, ihmeteltiin hyvän aikaa sitä, miten leukani aina vain kiristyy ja laulaminen sattuu. Ongelman pitkittyessä turhauduin useasti, kun sitä jouduttiin tunnilla yhä uudestaan käsittelemään. (Havukainen mpk2018: 7.)
}

Edellä kuvatussa äänellis-esteettisesti orientoituneessa tilanteessa opettaja tarkkailee kehollisen kuuntelutaitonsa avulla oppilaan fyysistä kokemusta orientaationsa mukaan. Kun opettaja takertuu pelkästään oppilaan sanoihin, oppilas kokee, että vain älyllisellä kertomuksella on merkitystä, ei fyysisellä kokemuk- 
sella. Kun oppilas puolestaan yrittää suoriutua opettajan asettamasta teknisestä haasteesta, hän turvautuu selityksessään tuttuun sanastoon, vaikkei todellisuudessa olisikaan kokemastaan varma.

\footnotetext{
Kohdallani leuan avaaminen meni lopulta niin pitkälle, että leukojani avaavat lihakset olivat laulaessani aivan ääriään myöten jännittyneet. Koin, ettei tämä avaaminen voi enää olla alkuperäisen jännityksen syynä eikä ainakaan auttaisi enää enempää keskittyä purentalihaksiini. Paneuduin itse syvemmin jännityksen tuntemuksiin ja oivalsin, ettei alkuperäisen jännitystilan tuottaja ollutkaan leuan, vaan kielenkannan jännittyneisyys. Juttelimme oivalluksestani opettajani kanssa, ja ongelma ratkesi. (Havukainen mpk2018: 7.)
}

Näin kehon tuntemusten tarkkailu, niiden sanallistaminen ja reflektointi auttoivat tilanteen etenemisessä. Opettajan äänellis-esteettisestä orientaatiosta huolimatta kehollis-äänelliselle reflektiolle löytyi opetustilanteessa myös tilaa. Vaikka siis esteettisyyden aspekti on laulutunnilla aina väistämättä läsnä erilaisten ääni-ihanteiden ohjatessa laulunopettajan toimintaa, on kuitenkin opettajasta riippuvaista, millä tavoin oppilaan keho ja nämä äänen esteettisyyden vaatimukset suhteutetaan toisiinsa.

Karkean kahtiajaon mukaan oppilaan laulamista muokataan laulutunneilla joko niin sanotun ihanteellisen äänen ja esteettisen muotin ehdoilla tai vaihtoehtoisesti kehoa kuunnellen ja sen ehdoilla työskennellen. Kokonaisvaltaisen kehollisuuden huomiointia pidetään näiden tyylien kesken joko yksiselitteisesti olennaisena osana laulunopetusta tai vähemmän huomionarvoisena, jolloin dualistisen ajattelun perinteeseen kumartava fyysisyyden tai henkisyyden korostaminen määrittyy opetusta ohjaavaksi arvoksi kokonaisvaltaisuuden sijasta. Käytännön opetustoiminnassa kokonaisvaltaisen kehollisuuden ja hyvinvoinnin arvot jäävät usein vähäisemmälle huomiolle.

Huolimatta siitä, että perinteinen kahtiajako esteettisen ja praksialistisen musiikkikasvatuksen kesken on puhututtanut tutkijoita jo yli kahden vuosikymmenen ajan, on kentällä silti havaittavissa edelleen urissa näihin kahteen pääleiriin jakautumista. Käytännön opetuksen kulttuurin voidaankin katsoa muuttuvan hitaammin kuin erilaisten opetusmetodien teoretisointien. Se, mikä käytännössä olisi mahdollista, on usein hyvän teorian perusta (Niiniluoto 2002: 11). Teorian 
kehittämiseen vaaditaan usein vain yksi ihminen, kun puolestaan institutionalisoituneiden käytäntöjen muuttamiseen saatetaan tarvita useamman sukupolven mittaisia keskusteluja ja aktiivista toimintakulttuurin muutoksen eteenpäin ajamista. Länsimaisen musiikkikasvatuksen perinteen mittakaavassa ei siis ole vielä mikään ihme, että vasta kahta vuosikymmentä aiemmin esitelty praksialistinen musiikkikäsitys nähdään edelleen käytännön tasolla usein ainoana vaihtoehtona esteettiselle musiikkikasvatukselle.

\section{Kehollinen empatia ja eettisyys}

Omassa opettajan työssäni olen kokenut empatian läsnäolon opetuksessa tärkeäksi, sillä se - eräänlaisena samastumisen mekanismina toisen ihmisen kehoon - auttaa minua kohtaamaan oppilaan kehollisen ymmärryksen tasolla. Neuropsykologisesti ilmaistuna tällainen kohtaaminen aktivoi ihmisen peilisoluja, ja nämä aktivoidut peilaamisen mekanismit auttavat ihmistä ymmärtämään toisen tekemistä oman kehonsa avulla (Karvonen 2017: 24). Kun opettajalla on itsellään jonkinlainen kokemus siitä, miltä erilaiset äänentuoton ongelmat tuntuvat, on helpompaa ymmärtää oppilaan vaikeuksia. Samastumista helpottavan kokemuksen puuttuessa tarvitaan puolestaan tarkempaa oppilaan tuntemuksen sanallistamista, jotta opettaja ymmärtää, mistä on kyse. Tähän samastumiseen vaikuttaa siis opettajan omien kokemuksien lisäksi hänen kommunikoinnin taitonsa: mikäli opettaja ei kykene samastumaan oppilaan kehollisiin tuntemuksiin tai kertomukseen siitä, jää oppilaan kokemusmaailma hänen tavoittamattomiinsa. Kun kokemusmaailmat poikkeavat toisistaan, ymmärretyksi tuleminen vaikeutuu ja asian oppiminen hankaloituu.

Oppimisen tutkimuksissa on saatu viitteitä siitä, että ihminen oppii parhaiten yhdistämällä näköhavaintoja, kasvokkaista kommunikaatiota, fyysistä toimintaa ja positiivista palautetta (Krause \& Sajaniemi 2012: 9, 14-15, 18-19), mikä puoltaa kokonaisvaltaisen kehollisen oppimisen tehokkuutta. Laulunopetuksessa nämä yhdistyvät näkö- ja kuuloaistien sekä kinesteettisten taitojen aktivoimisessa laulutunnilla. Kuuntelemalla oppimisen lisäksi oppilas oppii visuaalisesti katselemalla opettajan esimerkkiä, harjoittamalla laulamisen motoriikkaa ja saamalla 
positiivista palautetta tekemisestään. Laulunopetus voikin parhaimmillaan antaa oppilaalle voimauttavan kokemuksen oman kehontuntemuksen vahvistumisesta.

Positiivisten tunteiden, kuten iloisuuden, tyytyväisyyden ja kiinnostuneisuuden (Hofmann 2016: 19) liittymisen opiskeluun on todettu edistävän oppimista (Krause \& Sajaniemi 2012: 19). Positiivisten tunteiden vaikutuksessa ihminen on niin sanotusti avoinna ja vastaanottavainen uuden oppimiselle. Negatiivisten tunteiden kanssa käy puolestaan päinvastoin: ihmisen vastaanottavaisuus heikkenee, eikä yhtä tehokasta oppimista tapahdu. Positiivisten tunteiden vaikutuksen on havaittu korreloivan myös nielun väljyyteen (Tarvainen 2012: 93), mikä puolestaan linkittyy olennaisesti laulunopetuksen tavoitteeseen löytää sopivan rento ääntöväylä laulamiselle. Laulutunnilla nämä positiivisesti ja negatiivisesti värittyneet kokemukset muovaavat laulajan omakohtaista kokemusta itsestään laulun opiskelijana.

\footnotetext{
Muutamien opettajien kanssa tuntui, että opettajan oma ego ja epävarmuudet ohjasivat sitä, miten hän opetti, eikä opettaja varsinaisesti pyrkinyt ohjaamaan minua yksilönä kohti parempaa tietotasoa. (V1 k2019)
}

Vaikka laulutunnilla yleensä opettaja päättää hyödyntämänsä opetustavan mukaisesti, mihin eri asioihin opetuksessa keskitytään, kiinnittää oppilas kuitenkin jatkuvasti huomiota myös omaan tekemiseensä. Laulaminen on niin henkilökohtaista ja jopa intiimiä tekemistä, että oman äänen objektiivinen ja analyyttinen tarkastelu voi olla usein hyvin vaikeaa huomion suuntautuessa ensisijaisesti käsillä olevaan subjektiivisesti koettuun laulusuoritukseen. Haasteellista se voi olla erityisesti harrastajille, sillä laulun harjoittelua ei useinkaan motivoi haave ammattilaisuudesta vaan se, että laulaminen on hauskaa. Oppilaan tavoitteena ei siis aina välttämättä ole oppia havainnoimaan omaa kehoaan erityisen syvällisesti. Oppilaan itseensä kohdistama tarkkailu riippuu siten myös oppilaan omista motivaatioista sekä hänen tavastaan katsoa ja kokea maailmaa.

Opettajan eettiseen ohjenuoraan kuuluu oppilaan hyvä ohjaus, oppilaan kohtaaminen yksilönä ja oppimiseen positiivisesti kannustaminen. Mikäli opettajan tavoitteena on edesauttaa oppilaan positiivista, elinikäistä suhdetta musiikin harrastamiseen tai musiikin ammattilaiseksi tulemiseen, onkin tärkeää pohtia, millaisia eettisiä ohjenuoria opettajien tulisi noudattaa nykytutkimuksen valossa. 


\section{Lopuksi}

Olen tässä artikkelissa pyrkinyt erilaisia laulunopetuksen kontekstiin sijoittuvia kokemuksia tarkastellen vastaamaan kysymykseen, millaisia erityisesti kehollisuuteen liittyviä tapoja vallitsevassa laulunopetuksen kulttuurissa painotetaan nykypäivän hyvinvointi- sekä kehollisuusdiskurssien näkökulmista. Olen tuonut esille sen, millaista huomioarvoa ja millaisia asemointeja keholle ja kehollisuudelle annetaan laulutuntien kontekstissa käytännön tasolla.

Aineistosta on luettavissa, että laulunopetuksen kentällä nousee karkeasti jaotellen esiin kaksi toisistaan eroavaa pääsuuntausta, äänellis-esteettinen suuntaus ja kehollis-äänellinen suuntaus. Nämä opetuksen painopisteet heijastelevat erilaisia arvoja kokonaisvaltaista kehollisuutta kohtaan: keho asemoidaan joko aktiiviseksi, itsenään tärkeäksi toimijaksi, jota havainnoimalla tuotetaan vapaasti virtaavaa, väljemmin estetisoitua lauluääntä, tai sitten se redusoidaan fyysisen ruumiin ulottuvuudeksi ja äänenkäytössä hyödynnettäväksi mekanistiseksi välineeksi, jonka toimintaa muokkaamalla tuotetaan esteettisesti ihanteellista lauluääntä.

Nämä opettamisen tavat arvottavat siis kehollisuutta laulunopetuksessa eri tavoin. Yhtäällä korostuu laulua ja kehollisuutta koskevien viimeaikaisten tutkimusten suosittelema kokonaisvaltainen kehollisuus osana laulunopetusta, kun taas toisaalla taivutaan herkemmin dualistiseen ajatteluun eriyttämällä mieli ja ruumis itsenäisiksi toimijoiksi ulkoa määritellyn lopputuloksen tavoittamiseksi. Jälkimmäisessä vaihtoehdossa kehollinen kokonaisvaltaisuus jää laulutunnilla toteutumatta. Vaikka musiikin opettamisen tutkimuksessa on havaittu monia hyötyjä, jotka liittyvät kokonaisvaltaisen kehollisuuden huomioimiseen, dualistinen ajattelu elää edelleen vahvana laulunopetuksen kulttuurissa.

Soivan musiikin ja musiikin tekemisen tutkimus nojautuu enenevissä määrin kehollisuuden filosofiaan (Juntunen et al. 2018). Samalla suomalainen musiikkipedagogiikka kurottaa kohti oppilaslähtöisempää opettamisen tapaa (Opetushallitus 2017). Tässä murroksen vaiheessa ja tutkimusteoreettisessa ilmapiirissä sekä aikana, jolloin kehot ovat jatkuvasti esillä ja jatkuvan suorittamisen vaatimus vaanii uupumuksella uhaten mieliä ja ruumiita olemaan koko ajan jotain enemmän tai vähemmän, on tärkeää kääntää katseet sitä kohti, miten oikeastaan kehoja nykykulttuurissa kohdellaankaan. Toivon tämän artikkelin toimivan ava- 
uksena etnomusikologian ja musiikkipedagogiikan piirissä käytävään keskusteluun kehon erilaisista asemista ja näiden vaikutuksista laulunopetuksen sekä yleisemmin musiikinopetuksen käytäntöihin.

\section{Lähteet}

\section{Tutkimusaineisto}

Havukainen, Ida-Meri (mpk2018) Muistelupäiväkirja. Aineisto tutkijan hallussa.

V1-16 (k2019). Kuudentoista laulunopettajan ja -opiskelijan kyselyvastaukset heidän omista kokemuksistaan lauluoppilaina. Kyselyn toteuttaja Ida-Meri Havukainen. Aineisto tutkijan hallussa.

\section{Kirjallisuus}

Anderson, Leon \& Glass-Coffin, Bonnie (2013) “I Learn by Going. Autoethnographic Modes of Inquiry". Handbook of Autoethnography. Toim. Stacy Holman Jones, Tony E. Adams \& Carolyn Ellis. London: Routledge, 57-83.

Aromaa, Johanna \& Tiili, Miia-Leena (2014) "Empatia ja ruumiillinen tieto etnografisessa tutkimuksessa". Moniulotteinen etnografia. Toim. Pilvi Hämeenaho \& Eerika KoskinenKoivisto. Helsinki: Ethnos ry, 258-283.

Aura, Maarit, Laukkanen, Anne-Maria ja Ojala, Juha (2018) "Laulunopettajien yleisimmin käyttämät laulupedagogiset käsitteet". Ainedidaktiikka 2(2), 38-70. https:/ / doi.org/10.23988/ad.73222

Bochner, Arthur P. (2013) “Introduction: Putting Meanings into Motion. Autoethnography's Existential Calling". Handbook of Autoethnography. Toim. Stacy Holman Jones, Tony E. Adams \& Carolyn Ellis. London: Routledge, 50-56.

Chang, Heewon (2013) "Individual and Collaborative Autoethnography as Method. A Social Scientist's Perspective". Handbook of Autoethnography. Toim. Stacy Holman Jones, Tony E. Adams ja Carolyn Ellis. London: Routledge, 107-122. 
Debes, Remy (2017) "Empathy and mirror neurons". The Routledge Handbook of Philosophy and Empathy. Toim. Heidi Maibom. London: Routledge, 54-63. https://doi.org/10.4324/9781315282015-6

Eerola, Ritva (2008) "Laulajan arviointi - makuasia vai korvan harjaantuneisuus". Laulupedagogi 2008-2009. http:/ / www.laulupedagogit.fi/wp-content/uploads/2013/11/ Laulupedagogi_2007-2008_sisus.pdf. (luettu 11.2.2019)

Elliott, David J. \& Silverman, Marissa (toim.) (2014) [1995] Music Matters: A Philosophy of Music Education. London: Oxford University Press.

Fiske, John (1990) Introduction to Communication Studies. London: Routledge.

Granger, Colette A. (2011) Silent Moments in Education. An Autoethnography of Learning, Teaching, and Learning to Teach. Toronto: University of Toronto. https://doi.org/10.3138/9781442695641

Hautamäki, Tarja (toim.) (2002) Laulajan opas. Seinäjoki: Rytmi-instituutti.

Herrala, Helena (2015) Tytöt kaukalossa. Etnografinen tutkimus tyttöjen jääkiekkoharrastuksesta. Rovaniemi: Lapin yliopisto.

Hofmann, Stefan G. (2016) "The Nature of Emotions". Emotion in Therapy: From Science to Practice. Toim. Stefan G. Hofmann. New York: Guilford Press, 1-23.

Huhtinen-Hildén, Laura (2012) Kohti sensitiivistä musiikin opettamista. Ammattitaidon ja opettajuuden rakentumisen polkuja. Jyväskylä: Jyväskylän yliopisto.

Jaakkola, Timo (2012) "Liikunta ja koulumenestys". Aivot, oppimisen valmiudet ja koulunkäynti. Neuro- ja kognitiotieteellinen näkökulma. Toim. Teija Kujala, Christina M. Krause, Nina Sajaniemi, Maarit Silvén, Timo Jaakkola \& Kari Nyyssölä. Helsinki: Opetushallitus, 53-63. Juntunen, Marja-Leena (2009) "Musiikki, liike ja kehollinen kokemus". Musiikkikasvatus. Näkökulmia kasvatukseen, opetukseen ja tutkimukseen. Toim. Jukka Louhivuori, Pirkko Paananen \& Lauri Väkevä. Vaasa: Fisme, 245-257.

Juntunen, Riikka, Kesäniemi, Perttu, Palmén, Eeva, Repo, Venla, Sillanpää, Maija, Tiainen, Milla, Viherkoski, Essi ja Vuohtoniemi, Anton (2018) "Manifesti ruumiillisuuden merkityksestä musiikille ja musiikintutkimukselle". Synkooppi. https://synkooppilehti. wordpress.com/2018/07/13/manifesti-ruumiillisuuden-merkityksesta-musiikille-jamusiikintutkimukselle/. (luettu 4.5.2019)

Karvonen, Anu (2017) Sympathetic Nervous System Synchrony Between Participants of Couple Therapy. Jyväskylä: Jyväskylän yliopisto.

Klemola, Timo (2005) Taidon filosofia - filosofin taito. Tampere: Tampereen yliopisto.

Koistinen, Mari (2003) Tunne kehosi - vapauta äänesi. Ä̈̈nitimpurin käsikirja. Helsinki: Sulasol. 
Krause, Christina M. \& Sajaniemi, Nina (2012) "Oppimisen palapeli". Aivot, oppimisen valmiudet ja koulunkäynti. Neuro- ja kognitiotieteellinen näkökulma. Toim. Teija Kujala, Christina M. Krause, Nina Sajaniemi, Maarit Silvén, Timo Jaakkola \& Kari Nyyssölä. Helsinki: Opetushallitus, 8-21.

Lehikoinen, Kai \& Vanhanen, Elise (toim.) (2017) Taide ja hyvinvointi. Katsauksia kansain väliseen tutkimukseen. Kokos-julkaisusarja 1/2017. Helsinki: Taideyliopisto.

Leikola, Anssi, Mäkelä, Jukka \& Punkanen, Marko (2016) "Polyvagaalinen teoria ja emotionaalinen trauma" Duodecim 2016:132, 55-61.

Lindeberg, Anna-Mari (2005) Millainen laulaja olen. Opettajaksi opiskelevan vokaalinen minäkuva. Joensuu: Joensuun yliopisto.

Lindeberg, Anna-Mari (2009) "Opiskelijan vokaalinen minäkuva". Musiikkikasvatus. Näkökulmia kasvatukseen, opetukseen ja tutkimukseen. Toim. Jukka Louhivuori, Pirkko Paananen \& Lauri Väkevä. Vaasa: Fisme, 233-244.

Lyyra, Riina (2017) Kehon ja mielen yhteyden vaikutus hyvinvointiin. Opinnäytetyö, oAмк. https:/ / www.theseus.fi/bitstream/handle/10024/125588/Lyyra_Riina.pdf?sequence=1. (luettu 12.1.2019)

Merleau-Ponty, Maurice (2012) [1945] Phenomenology of Perception. London: Routledge. https:/ / doi.org/10.4324/9780203720714

Niiniluoto, Ilkka (2002) "Käytäntö-kollokvion avaussanat". Käytäntö. Toim. Sami Pihlström, Kristina Rolin \& Floora Ruokonen. Helsinki: Yliopistopaino, 8-13.

Numminen, Ava (2005) Laulutaidottomasta kehittyväksi laulajaksi. Tutkimus aikuisen laulutaidon lukoista ja niiden aukaisemisesta. Helsinki: Sibelius-Akatemia.

Ogden, Pat \& Fisher, Janina (toim.) (2015) Sensomotorinen psykoterapia. Keinoja trauman ja kiintymyssuhdevaurioiden hoitoon. Helsinki: Traumaterapiakeskus ry.

Opetushallitus (2017) Taiteen perusopetuksen yleisen oppimäärän opetussuunnitelman perusteet 2017. Helsinki: Opetushallitus. https://www.oph.fi/download/186919_Taiteen_perusopetuksen_ yleisen_oppimaaran_opetussuunnitelman_perusteet_2017.pdf (luettu 1.5.2019)

Richter, Philipp \& Hebgen Eric (toim.) (2010) Triggerpisteet ja lihastoimintaketjut osteopatiassa ja manuaalisessa terapiassa. Helsinki: Otava.

Shusterman, Richard (2008) Body Consciousness. A Philosophy of Mindfulness and Somaesthetics. Cambridge: Cambridge University Press. https://doi.org/10.1017/ св09780511802829 Sinkkonen, Jari (2009) "Musiikki - yhtä aikaa yksilöllistä ja jaettua". Musiikkikasvatus. Näkökulmia kasvatukseen, opetukseen ja tutkimukseen. Toim. Jukka Louhivuori, Pirkko Paananen \& Lauri Väkevä. Vaasa: Fisme, 289-297. 
Sonninen, Aatto (1990) "Laulupedagogia ja tiede". Laulupedagogi 1989-1990. Helsinki: Laulupedagogit ry., 70-71.

Tarvainen, Anne (2012) Laulajan ääni ja ilmaisu. Kehollinen lähestymistapa laulajan kuuntelemiseen, esimerkkinä Björk. Tampere: Tampereen yliopisto.

Tiainen, Milla (2012) Becoming-singer. Cartographies of Singing, Music-making and Opera. Turku: University of Turku.

Turunen, Serja (2016) Matkalla musiikkiin. Fenomenologinen tutkimus peruskoulun 3.-4.-luokkalaisten taidemusiikin kuuntelukokemuksista koulun musiikkikasvatuskontekstissa. Joensuu: Itä-Suomen yliopisto.

Tiainen, Milla \& Kontturi, Katve-Kaisa (2007) "Taide, teoria ja liikkuva vuorovaikutus: osallistuvan taiteentutkimuksen ratkaisuja". Taiteilija tutkijana, tutkija taiteilijana.Toim. Risto Pitkänen. Jyväskylä: Nykykulttuurin tutkimuskeskus, 13-65.

Uotinen, Johanna (2010) "Aistimuksellisuus, autoetnografia ja ruumiillinen tietäminen". Elore vol. 17 - 1/2010, 86-95. https:/ / doi.org/10.30666/elore.78851

Yle (2010) "Nuoret väsyvät opiskeluun musiikkiopistoissa". https:/ /yle.fi/uutiset/3-5568017. (luettu 14.12.2018) 